SECTION 29. Literare. Folklore. Translation Studies.

Rakhmatullayeva Shakhodat Ziyetovna senior teacher of the Department of the Uzbek language and literature, Karshi State University (Uzbekistan)

\title{
ON NATIONAL-CULTURAL SIGNIFICANCE FORMS THE IMAGE OF THE ACTIONS OF THE UZBEK LANGUAGE
}

Language is a mirror of the national mental culture that originally passed in a language unit of each tier. It should be particularly stressed wide possibility of transfer of national mentality, demonstrate the level of a culture of communication by grammatical forms, which are the means of implementing, specify, and can adapt to the speech values of lexical units of the Uzbek language.

Keywords: national characteristics, culture.

\section{О НАЦИОНАЛЬНО-КУЛЬТУРНОЙ ЗНАЧИМОСТИ ФОРМ ОБРАЗА ДЕЙСТВИЯ В УЗБЕКСКОМ ЯЗЫКЕ}

Язык - зеркало национально-ментальной культуры, которая своеобразно передаѐтся в языковой единице каждого яруса. Особо следует подчеркнуть широкую возможность передачи начионального менталитета, демонстрачии уровня культурь общения путѐм грамматических форм, являюшихся средствами, реализовывающими, конкретизирующими, а также приспосабливающими к речи значений лексических единии узбекского языка.

Ключевые слова: национальные особенности, культура.

В этом смысле, доказательством могут служить выделение категории уважения [1], затем функционально-семантического поля уважения [7], категории образа действия.

В ментальном мире узбекского народа особое место занимают уважение, скромность, деликатность, которые всегда выражаются в диалектной гармонии. Они выражают дух народа, его духовный облик, уровень человеческих качеств. Сравнение значения слова андиша в узбекско-русском словаре показывает уровень концептуальной значимости данного слова. Слово андиша [6. с. 81] в узбекском языке переводится на русский целым рядом слов: благоразумие, осторожность, осмотрительность, предусмотрительность, деликатность, тактичность, мысль, дума, помышление, соображение, забота, стыл, совесть [4, с. 31]. Однако все выше перечисленные слова русского языка имеют свои эквиваленты в узбекском. Например, совесть 
- виждон, забота - вамхўрлик, осторожность - эхтиѐткорлик, мысль фикр, дума - уй-хаѐл, деликатность - хушмуомалалик, назокатлилик, мулойимлик, благоразумие - мулохазакорлик, помышление - ўй, фикрламоқ. Следовательно, значение слова андиша широко и многогранно, его сложно передать словами других языков.

В передаче национальных особенностей уважения, деликатности и скромности одинаково участвуют языковые: лексические, морфологические, синтаксические и экстралингвистические средства.

Отдельные языковые средства играют особую роль в выражении ментального значения -андиша". Например, в их числе можно перечислить форму побудительного наклонения -синлар шакли, местоимение ўзлари, личные формы глагола, категорию числа. Нельзя провести четкую грань между категориями андиша (деликатность) и уважения в узбекском языке. В силу этого, когда речь идѐт о средствах функционально-семантического поля уважения в узбекском языке, следует особо подчеркнуть диффузное выражение значений «деликатности» и «уважения» путѐм одного грамматического средства [7].

Формы действия помимо реализации лексического значения глагола, речевой специализации, модификации, также выражают ментальное отношение говорящего к слушающему, его манеру, уровень культуры и разум, в которых ярко передаѐтся узбекская деликатность. При этом особую важность имеет строение форм образа действия, с помощью какого средства вспомогательный глагол связывается с главным. Точнее, форма образа действия, с одной стороны, реализует эти значения, а с другой, коммуникативная интенция говорящего и его ментальная культура требует реализации данных форм образа действия.

Обратимся к примерам: 1. Мехмон бу хуақда берган саволларимга жавоб бермасдан илжайиб туриб-туриб, туссатдан: - Думли одамларни курганмисиз? - деди. Мехмон гапнинг сархонасини янгиламоқчи деган уйда кулиб куия қолдим. (А.Қах.) 2. Мен бу гапга унча овринмадим, эркак киши баъзан шунаққа юраги торлик құлади, деб кууя қолдим. (А.Қах.) 3. Эри бор пайтда салом берсангиз, «бекор айтибсан» деганга уухшаб алик оладиган одам, жуда ширин сузз бўлиб хзол-ахвол сўради, хзовлимни супуриб берди, хуатто бошимни уққалаб куйди. Ичимда «еелвизлик кор құлибди-да» деб куия қолдим. (А.Қах.) 4. Фотима унинг эрдан чиққанини дадасига айтмай кўя қолди, ярашиб кетар, деб уйлади. Фотиманинг дами ичига тушиб кетди. Шу аснода Самижон кириб келди. Фотима икковини таништиришини хуам билмай қ̧олди, таништирмаслигини хуам, лекин унинг Зухрага томон илжайиб бораеттганини куириб "Самижон!" дейишга мажбур бўлди. Зухра куѐв шу эканини билиб, унга кўз құрини ташлади, хиндчасига кафтларини жуфтлаб таъзим қилиб куия қолди. (А.Қаххор.) 
Формы образов действия в контексте образуют цепь образов действия. В первом тексте главный глагол - кулмок, во втором и третьем текстах демоқ, в четвѐртом таъзим қиллоқ.. Словоформами главного глагола считаются глаголы кулиб куймоқ, деб куййоқ, таъзим қилиб куййок.

Известно, что использование формы образа действия қўя қзолмоқ по отношению к явлению или событию выражает безразличие говорящего, если речь передаѐтся в первом лице, и безразличия субъекта, если глагол выражен в 3-ем лице. Например, это можно проследить в следующем предложении: Яхшилаб тушунтирилгач пристав битта кулангир, битта фаранги товуқ, уч сўм пулни олганидан кейин, Қобил бобонинг бахтига, "бетухттов хуокимга хабар бераман" демасдан, "аминга бор", деб куия қолди. (А.Қаххор). Однако, в выше приведѐнных текстах цель деликатности реализуется наряду со значениями «сдерживания себя от ненужных слов», «стремления не причинить боли другому человеку». Ибо, сдержанность, старание не причинить боль кому-либо являются своеобразными видами деликатности. Средства деган ўйда в первом тексте, унча огринмадим во втором, ичимда в третьем и куиз қирини ташлади в четвѐртом имеют статус укрепляющих факторов, указывающих на то что, форма образа действия является средством выражения деликатности.

Следовательно, форма образа действия қўя құлмоқ образованная с помощью средства - $а$ қ̧олмоқ имеет особую значимость при выражении состояния деликатности.

Форма образа действия - $а$ қ̧олмоқ в случае использования по отношению ко второму или третьему лицу в повелительной форме значения «просьбы», «мольбы», «извинения» реализуются как частные виды просьбы. Например: 1. Эй, йўловчи, буула қол қўноқ, Уйда борин кўрамиз бахам. (А.Орип.) 2. Озодлик, йуллингzа гов бўлганларга Найзадай санчил-у, тезроқ булла қол... (А.Орип.) 3. Сен - булбулсан, булбулларни маст қила қол, булбулим, Менинг учун сайрашингни бас қила қол, булбулим. (А.Орип.) 4. Ётар пайтинг бўлди-ку дер, Кела қол, дер, болажон. (А.Орип.) 5. Шундай пайтда уузинг айлагил шафқ̧ат, Сингил бўла қолгил, менга, табиат. (А.Орип.)

Форма образа действия - $а$ mур служит для образования более «смягчѐнной» формы повеления, при этом значения «уважения» выражается в частных формах: 1. Хўп. Хадисингизни куия туринг. Ўиа куни эрталаб Шоматовларнинг подъездидан биронтаси чиқмадими? (Ў.Хошимов) 2. Афгонистонни кўл турайлик, ўртоқ прокурор! - дедим хзорвин охангда. - «Икки юзинчи» юк фақ̆ат Афвонистондан эмас, мамлакат ичкарисидан хуам ѐzилиб келяпти. Уларнинг хунини ким тўлайди? Ўзбек халқ̧ини бутун мамлакатга бадном құлганлар эмасми? (Ў.Хош.) 3. Салкам уч ой бор. Ўйласам, вахмим келур. - Вахмни куия 
туринг. Хозир фахрдан гап очдингиз-ку. (П.Қод.) Естественно, в словоформе куия туринг диффузионное выражение ряда ментальных особенностей, как деликатность, уважение, внутренняя культура проявляется больше нежели в словоформе куййин.

Конечно, не следует искать значения деликатности, уважения, просьбы в каждой форме образа действия. В отдельных формах образа действия негативное отношение говорящего может выражаться в сочетании со значением «неуважения». Например, формы образа действия - $а$ сол, $-a /-(u) б$ ташла, -и(б) ўл, -a/ŭ кет в случае, когда речь идѐт о действиях другого человека, используется для выражения негативного отношения, а следовательно, «неуважения». Обратимся к примерам: 1. - Исанмисиз? - деб суррамади-ю, хуасратини тўкиб солади. - Китти, сволиш! Яна уйнашива китти, паразит. (Ў.Хош.) 2. У хира патшадек бемаъни виндиллаган саволларни угша захоти кувиб солади. (Ў.Хош.) 3. Кучум бошини сарак-сарак қ̧илди. - Энди у томонга йўл йўқ. Улар мени сафларига олмайдилар. Қуйларимизни яна дарѐдан уттқазиб чет элга опқ̧очиб кетади, деб кувиб соладилар. Итга талатадилар...(С.Ахмад). Другими словами, в случае когда говорящий с высоким уважением относится к субъекту действительности, передаваемым им, выражает уважение и почтение к его мыслям, что проявляется в использовании форм образов действия, а также других грамматических форм. В частности, семантические особенности использования формы - $(u) б$ в приведѐнных текстах определяются также неиспользованием личных аффиксов, выражающих значения уважения этих глаголов. Иными словами, формы образов действия и личные аффиксы в речи реализуются как дополняющие и укрепляющие друг друга средства. Или же в словоформах айтиб ташладилар, уйинай кетдилар, кувиб етдилар можно заметить противоположное тому явление. Как было отмечено выше, когда отношение негативное или нейтральное используется форма образа действия -(u) 6 ташла, а в данных сочетаниях отмечается их несоответствие аффиксам личности, выражающих значение уважения. В процессе наших наблюдений нам не пришлось столкнуться с подобными ненормативными употреблениями.

И в заключении можно сказать, что в составе форм образов действия существуют также грамматические средства, ярко отображающие национально-ментальный образ узбеков, уровень культуры общения, употребление которых непосредственно связаны с уровнем культуры говорящего, его отношения к адресату, а также социальными и прагматическими факторами.

\section{Литература}

1. Зикриллаев Ғ.Н. Феьлнинг шахс, сон ва хурмат категорияси системаси. - Тошкент., Фан, 1990. 
2. Менглиев Б., Холиѐров Ў. Ўзбек тилидан универсал кўлланма. Тошкент: Академ нашр, 2011.

3. Сайфуллаева Р., Менглиев Б. ва бошқ. Хозирги ўзбек адабий тили. Дарслик. - Тошкент: Фан ва технология, 2010.

4. Узбекско-русский словарь. - Ташкент: Ўзбек совет энциклопедияси бош редакцияси, 1988.

5. Шукуров О. Харакат тарзи шакллари парадигмаси: Филол. фанлари номзоди. ...дисс. автореф. - Самарқанд, 2005.

6. Ўзбек тилининг изохли луғати. 5 жилдлик. 1-жилд. - Тошкент: Ұззбекистон Миллий энциклопедияси нашриёти" Давлат илмий нашриѐти, 2006.

7. Хожиева Х. Ўзбек тилида хурмат майдони ва унинг лисоний-нутқий хусусияти: Филол.фанлари номзоди ...дисс. автореф. - Самарқанд, 2001. 